\title{
Migration, multiculturalism, human rights and the paradigm in the actual international politics (re)action
}

\author{
Ana CAMPINA ${ }^{1}$, Carlos RODRIGUES ${ }^{2}$ \\ ${ }^{1}$ Professor, Universidade Portucalense, Law Department, Instituto Jurídico Portucalense (IJP), Porto-Portugal, \\ Orcid ID=0000-0003-0820-1280 \\ ${ }^{2}$ Professor, Instituto Jurídico Portucalense (IJP), Porto-Portugal, Orcid ID=0000-0003-0966-6274 \\ Email: ana.campina@gmail.com,crodrigues@upt.pt
}

\begin{abstract}
2020 has been an unquestionable challenge for the Humanity and the world course that was decided based in a completely unknown future. The enemy - the virus - is invisible but the worst and more aggressive threat to the Human Being. There is no medicine or treatments against the COVID-19 and there are no real expectations to find it in the near future. The world numbers of the Human Beings death and infected by the SARS-COV are serious and obliged a never known full world stop. The Humans were mostly afraid and impotent to fight with this dangerous virus; the politicians mostly connected to combat the immediately Public Health and try to answer the needs of the millions affected, directly or indirectly; the economies full stopped, crashing; the companies and institutions - private and public - without conditions to combat and break their immediately needs. The world faced one of the most serious and difficult challenge in the Contemporary History, and it is being designed a New World Order. Concerning the political reply to this unexpectable and serious context, the States and International Organizations were working together, however, there are a completely different politic answer and (re)action in different States America.
\end{abstract}

Key words: Human Rights; Migration; Multiculturalism; International Politics

\section{Introduction}

Although all the complex Pandemic context to the Humanity, in general, there were an important connection between governments, politicians, economies, finances, cultures and religions, in domestic, regional and international scenery, all around the world during the Pandemic hardest situation. This is not a situation solved and it's not preview to be solved in next future - there are important and serious problems affecting millions that in this context just were dangerously exacerbated. It is serious and urgent a global joint campaign to call for the attention and appeal to the responsibility - specially the Governments, the group of States and International Organizations, and the societies - to the problems that didn't disappear within the world is concentrated in Pandemic fight: the poverty increase, serious diseases without medical treatment provoking the worst health consequences, including undefined number of deaths; unemployment of millions; starvation; the migrants and the refugees without any protection or support, by the states, International Organizations (Governmental or Non-Governmental) leave "alone" due the Pandemic legal demands of confinement, and so many other serious human problems leave "stand by" during the hard impact of COVID-19 and there were worsened. In this context, specially by the Worth Health Organization analysis and general guidelines, the International Politics have been mostly concerted, but there have been the a kind of negligence of the effective protection of the Human Rights with such serious consequences that we cannot have the real information but that needs an immediately action from the responsible as the States and the International community, avoiding the deterioration of the whole worst violations of the rights of millions around the world.

The main subjects we were studying by a focus research, as we consider the main relevance to promote education within the academic, scientific, juridical, political and social audience and concerns, we the following: Slavery Abolition: International Law (2020); Abolition of Slavery in USA: an endless history?; Nelson Mandela: a life fighting for multiracial acceptation in South of Africa; Aung San Suu Kyi, "The Lady" (Nobel Peace Prize 1991) - "an outstanding example of the power of the powerless" and international symbol of peaceful resistance and fight for democracy in the face of oppression in Myanmar; Actual reality (2020): Violent demonstrations against racism in USA; Violence against racism in South of Africa; Rohingya and the Myanmar: the genocide; UN reaction to the Slaves Market in North Africa....the discourse over the reality!

This research was designed aiming promote knowledge and debate on a legal basis and, as the inherent comparative law and international contexts obliges to have in concern the scope of the legal epistemology, as affirmed by Geoffrey Samuel, supported by the qualitative method, it's required the comparison 
between different legal, political and economic contexts. So, the research and presentation of different graphics and maps, was a challenge to demonstrate our main point of views. This way, we formulated the study by the theory in accordance with the need of the demonstration of the distance / similarities with the reality of the complex and different subject. Finally, the dialectical methodology scheme, in different ways, was applied to explain the contradictions finding in this study.

\section{Abolition of Slavery in USA: an endless history?}

Hereby the timeline of the abolition of the slavery, and it's really important to understand the evolution by the legal perspective, as well as, it is easily to identify the countries where the slavery is a real although the abolition by law, including United States. This is dramatic by the judicial point of view, as there are millions of responsible that were not judge, as well as by the political power that mainly doesn't assume their responsibility identifying and taking action these serious situations affecting human beings unprotected by their own state, living their fundamental and human rights violated.

It's important to be aware that after the XVIII century, only, the process of the slavery abolition, at least at legal level, was started in the most part of the countries, but in different Asian and African countries, this legal abolition only was a reality in XX century.

It's important to be aware that only after XVIII century the slavery, at least at legal level. (Figure 1)

Figure 1

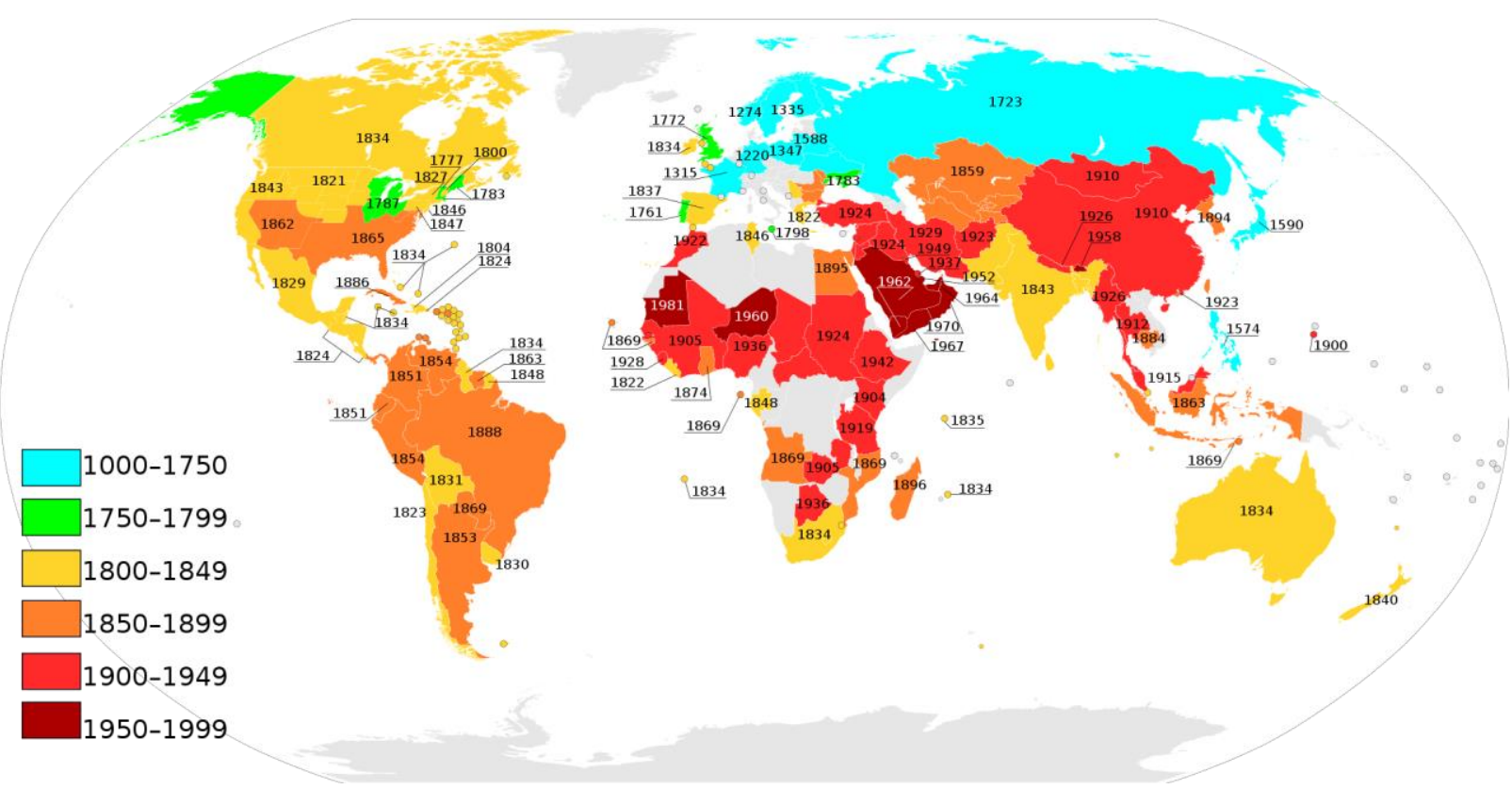

Source:https://en.wikipedia.org/wiki/Timeline_of_abolition_of_slavery_and_serfdom\#/media/File:Slavery_abolition.svg

It's important to understand the history of the Slavery in United States to understand the evolution of this phenomenon: in 1619, a ship with 20 captives landed at Point Comfort in Virginia, ushering in the era of American slavery; After the first captives were forced on to Virginia's shores by a Dutchman in 1619, the majority of the country remained white and relied mainly on the labor of Native American slaves and white European indentured servants. It was not until the end of the 17th century that the transatlantic slave trade made its impact on the American colonies. As the following (Figure 2) 
Figure 2

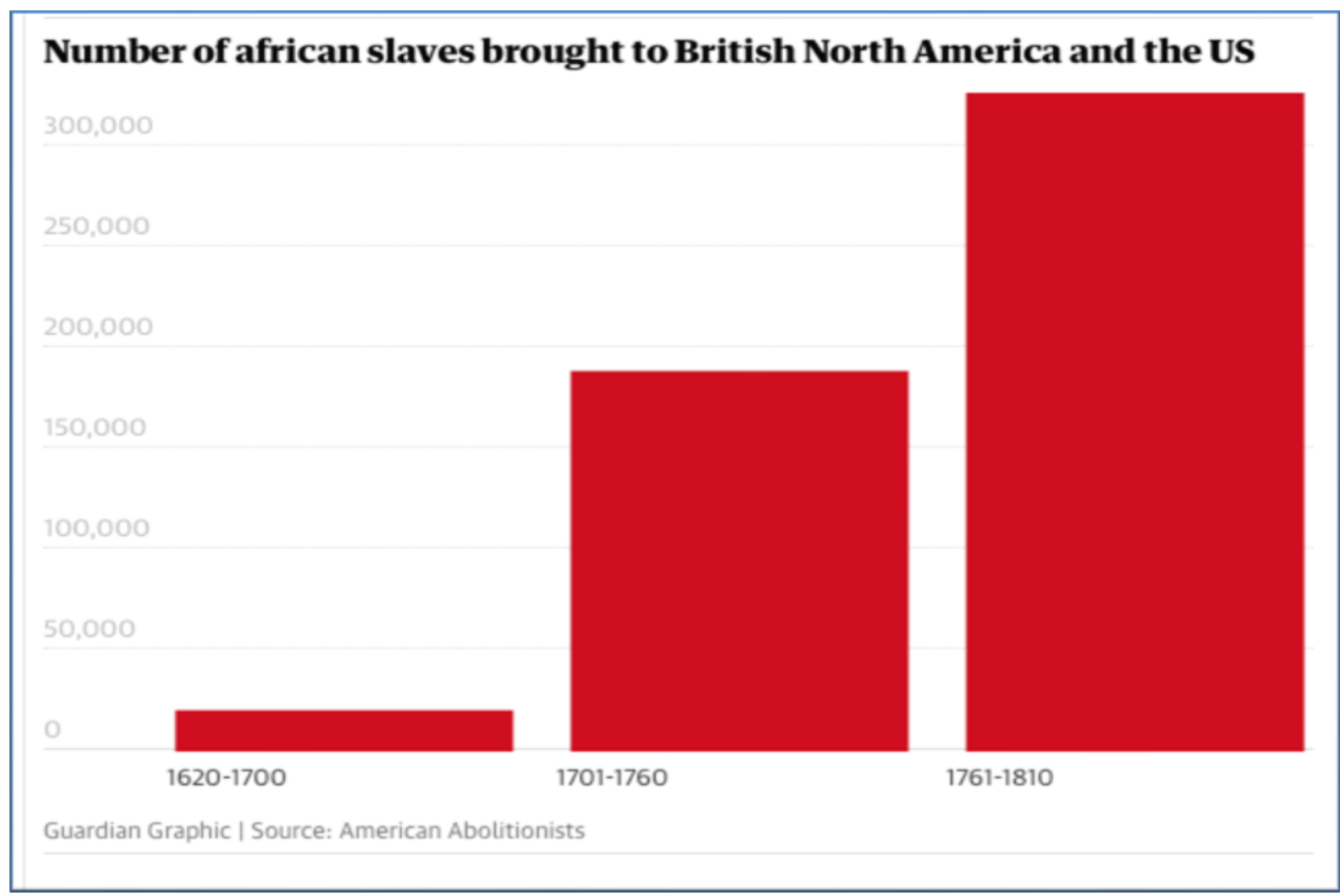

Source : https://www.theguardian.com/news/2019/aug/15/400-years-since-slavery-timeline

There is a relevant US Census from 1790 that shows the states of US, the productions where slaves were used to explore (Figure 3)

Figure 3

\section{US Census}

At the time of the first US Census, non-white slaves accounted for a sizable portion of the population of southern states

\begin{tabular}{llcc} 
State & A Crops & Total population & $\begin{array}{l}\text { Percentage of population that } \\
\text { were slaves }\end{array}$ \\
\hline Virginia & Tobacco & 747,610 & $39.1 \%$ \\
North Carolina & Tobacco, cotton & 395,005 & $25.5 \%$ \\
Maryland & Tobacco & 319,728 & $32.2 \%$ \\
South Carolina & Rice, indigo, cotton & 249,073 & $43.0 \%$ \\
Georgia & Rice, indigo, cotton & 82,548 & $35.5 \%$ \\
\hline
\end{tabular}

Guardian graphic | Source: Kolchin, Peter. American Slavery, 1619-1877 and IPUMS NHGIS, University of Minnesota, www.nhgis.org 


\section{Slavery Abolition: International Law (2020); Abolition of Slavery in USA: an endless history?} Considering the Declaration of Independence of US from 1776, stating "that all men are created equal, that they are endowed by their creator with certain unalienable rights", in fact the Africans or African Americans slaves didn't have this right recognized, as the final version didn't denounce the slavery. But, although Thomas Jefferson being a slaveowner, wrote some words rejecting slavery that was removed after some criticism from delegates what different scientists consider as the beginning of the American political economy. So, the tobacco fields were the initial slavery ground that spread to the rice plantations and until the $20^{\text {th }}$ century the African Americans remained the majority.

In 1926 Jim Crow provided the African Americans shut out of jobs and opportunities, what was the opportunity to promote migration of more than 2 million southern African Americans migrated running way from the discrimination and exploitation, especially after the I World War. However, the "normal" life for the black people was not a reality as they have specific rules as restriction of movement in the end of the day and the places where they are allowed to live in the cities. This means the segregation was a serious reality, as in Oregon's that didn't allow the black people to enter the state.

The movement of integration of black people and defenders of the civil rights had to continue fighting as in 1954 the supreme court ruled that segregation was unconstitutional and schools would have to integrate, but the 60s were scene of anti-segregation marches in United States and only on 1964 President Lyndon Johnson signed the Civil Rights Act into law, and 1965 was the date of the Voting Rights Act prohibiting racial discrimination in voting.

So, we can conclude that the slavery, the segregation, protected by the political power, the difficulty in protecting millions of human beings by the law, the difficulty of the judicial courts in putting in practice the equality for all citizens in all states along the United States, is the most important explanation for the nowadays serious and complex context of the discrimination between black and white North American citizens, problem far way of the solution (Figure 4).

Figure 4

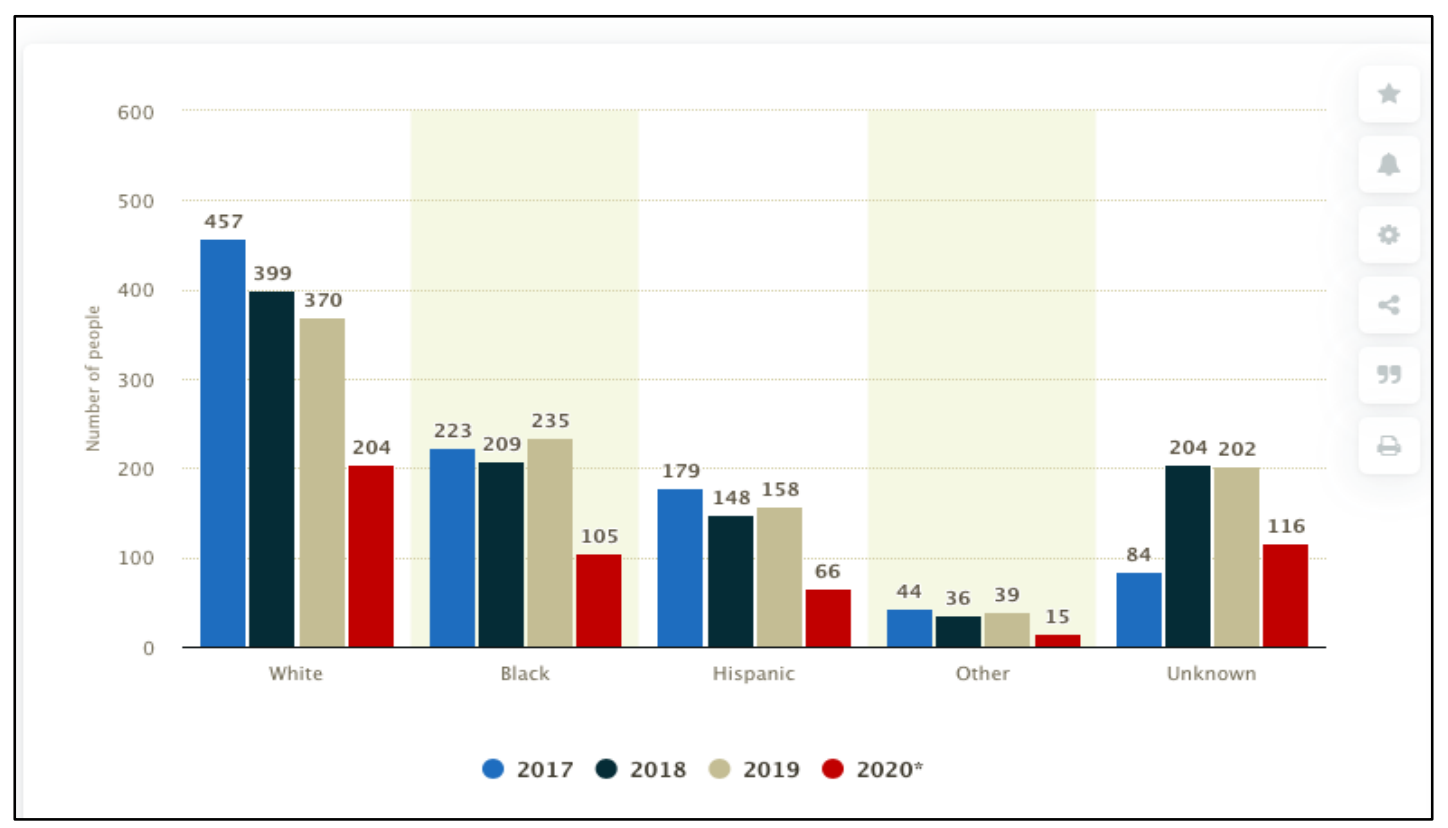

Source: Statista in https://www.statista.com/statistics/585152/people-shot-to-death-by-us-police-by-race/

Unfortunately, the racism, discrimination and violence are a reality and, the United States police has been an important (negative) "actor". The United States police has shot to death from 2017 to 2020 and the numbers by race are really serious as it has increased in 2020 (January-June) and the number of Black Americans - 31 deaths - was much higher from any other races. The Federal State is aware, as the International Community is assisting and asking for action by the United States and the International legal 
and judicial system, but the police brutality has increased. In fact, from 2013, there is an important Movement - Black Lives Matter - as a vocal part of the movements against the police violence, acting by the denouncing and asking for the attention and action of the International Community by marches, demonstrations, especially as a reaction of the killings of American Blacks by the police of their own country. Obviously the Human and Civil Rights are being violated, in particularly by those who should protect these human beings - the police - and although the international claim of justice, the "way" is long and hard, as the discrimination, racism and xenophobia is "alive" and difficult to stop as the political, legal and social authorities need to act to avoid the continuous of these unhuman behaviors in the $21^{\text {st }}$ Century with the existence of all national, international legal instruments to protect the Human and Fundamental Rights, as well as, to punish all the violators.

\section{Nelson Mandela: a life fighting for multiracial acceptation in South of Africa}

Research and understand the Migration, multiculturalism and human rights to achieve to the actual international politics reaction, obliges to analyze one of the most hard but important period in South Africa and Nelson Mandela fight.

In order to understand the racial relationship in South Africa, there is a graphic with data that highlight the situation since the born until the death dates of Nelson Mandela (Figure 5).

Figure 5

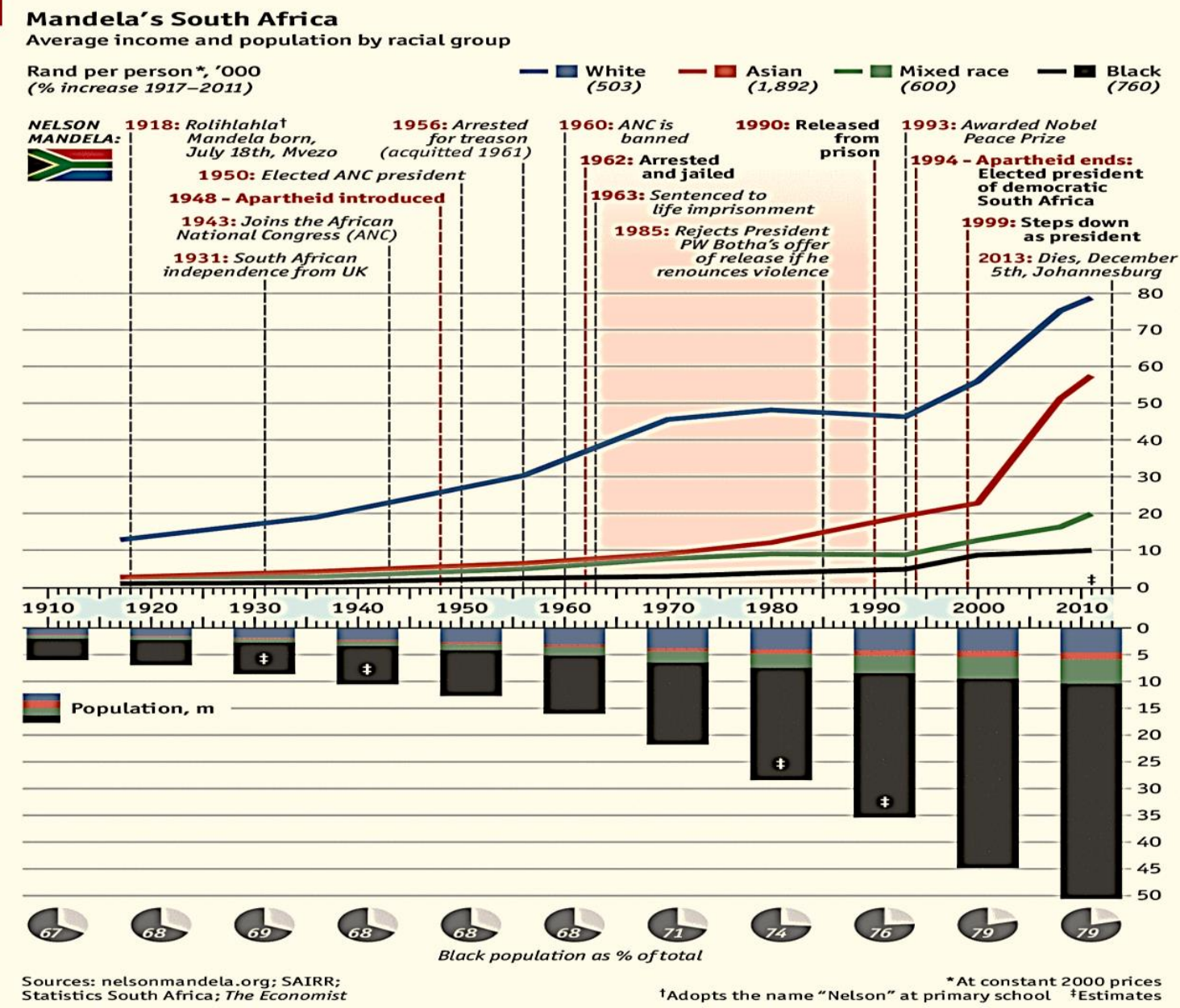

Economist.com/graphicdetail

We can state that Nelson Mandela lived his life fighting for multiracial acceptation in South Africa and he said "our march to freedom is irreversible. We must not allow fear to stand in our way" and "it will forever remain an indelible blight on human history that the apartheid crime ever occurred". Looking for the future generations and the fight for democracy and Human Rights and the adoption of the universal declaration, as a body of law, as the political and social order of the (renew) state - South Africa. So, as we can understand, Nelson Mandela, Apartheid and Education in this country was the main demand for the future, avoiding the discrimination, racism, xenophobia and violence, as well as, political power action 
over the International legal system, violating the Human Rights. The Nelson Mandela amazing but hard and suffered life was the biggest part of "longer walk to equality" that is not completed as the life in South Africa faces step backwards and the races are still fight for the equality, as following graphic illustrations (Figure 6).

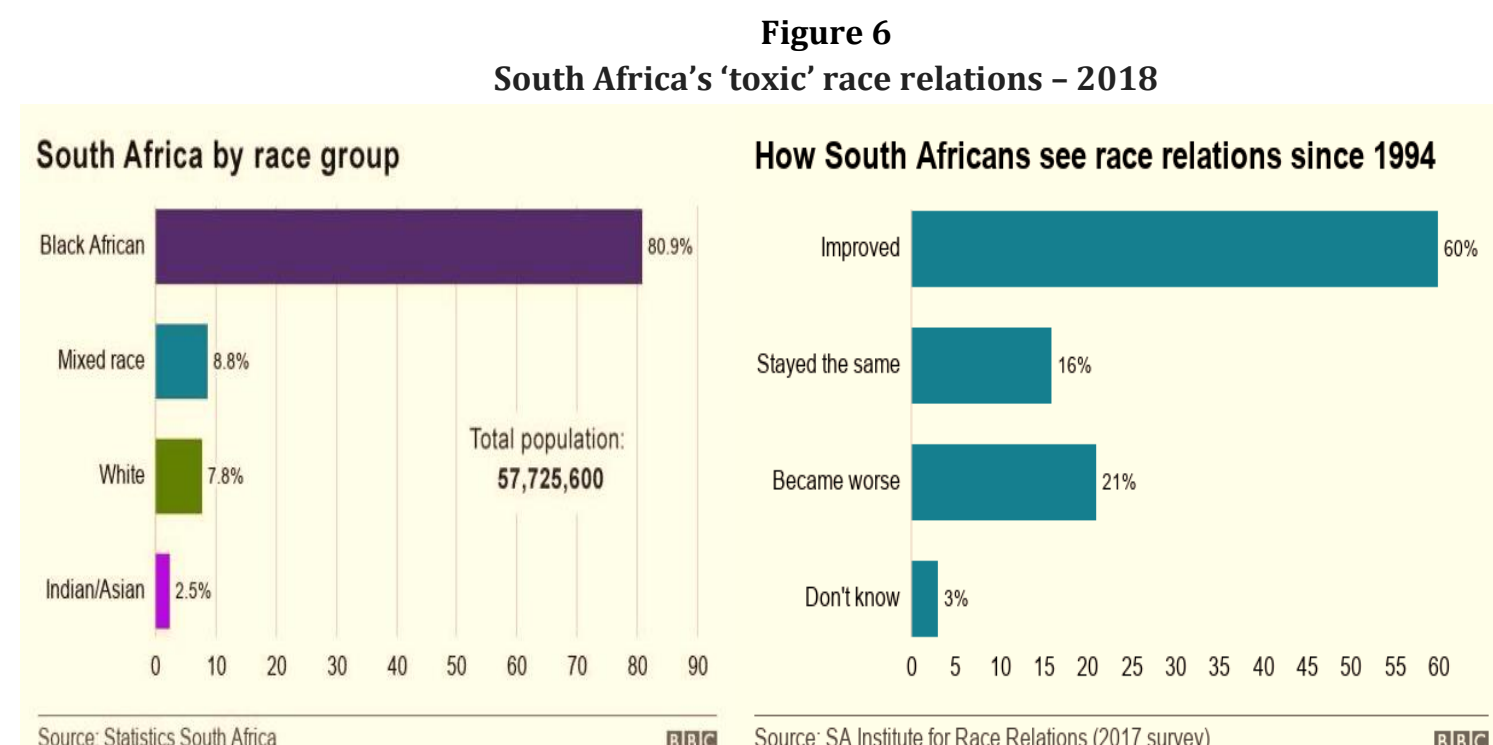

Source : https://www.bbc.com/news/world-africa-46071479 ?ocid=socialflow_twitter

Live and survive in South Africa is really difficult and a fight for millions to survive and have different opportunities - work, home, family and security, school access, economic conditions, health access, cultural freedom, ... - is different between races and ethnics, being predominant the Black African. However, relationship between Black African and other races are not pacific, although the national and international legal system recognize the Human and Fundamental rights for all citizens, and international community continue acting to avoid the violence and the violation of these rights, mostly without the success needed.

So, Nelson Mandela devote all his life in this hard fight, and it's an example to the world, there are followers inside and outside South Africa, but there is a continuous work need for all involved in political, legal, judicial, social and cultural system, being important to demand to the international community, and the International Organizations develop their work promoting and protecting the Human Rights of millions.

\section{Myanmar and the Rohingya Genocide: the (strategic) world disregard}

Figure 7: Myanmar Map

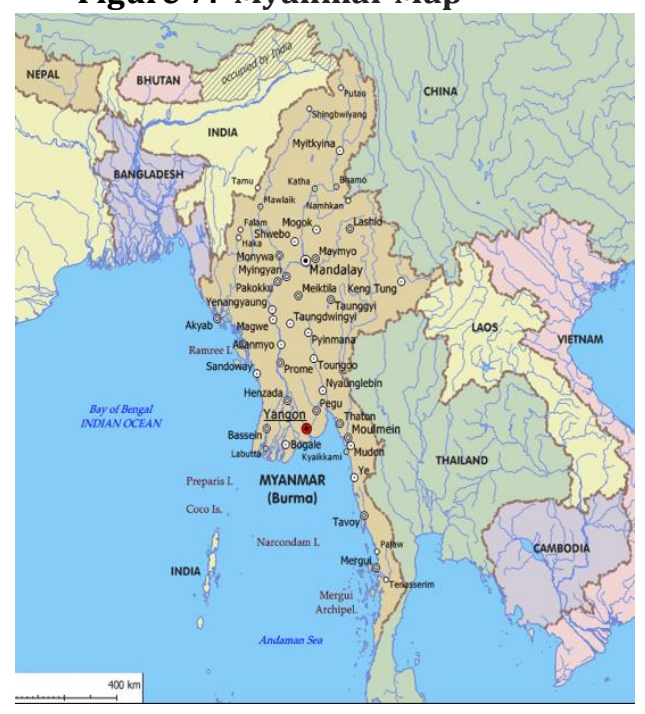

Along decades there is a serious problem in Myanmar named as Burma until 1989, the second largest country in mainland Southeast Asia, bordered by China, Laos, Thailand, Bangladesh and India - the more than 2 million Burmese that have been forced to seek refuge abroad (particularly in Thailand and Bangladesh)

There is a relevant political context - the Aung San Suu Kyi - a women elected by free elections in 1990 but it was annulled by the Burmese government and she was arrested and was in an out of military confinement more than a decade, and in 2000 was arrested in her own house for more a decade. Just in 2016 Aung San Suu Kyi was elected again and, by the growing power of the democratic movement, in spite of the legislative and executive control of the military, she assumed (Figure 7)

Source : 
https://www.caingram.info/Myanmar/Myanmar_map.htm

In order to have the conscious of the suffering that Rohingya refugees are facing, we introduced the Figure 8 that we'll explain.

Figure 8

Rohingya "Ethnic Cleansing" Leads to Refugee Crisis
Figures related to the forced displacement of Myanmar's Rohingya population

\section{3,000}

people estimated to have fled to
Bangladesh from Myanmar

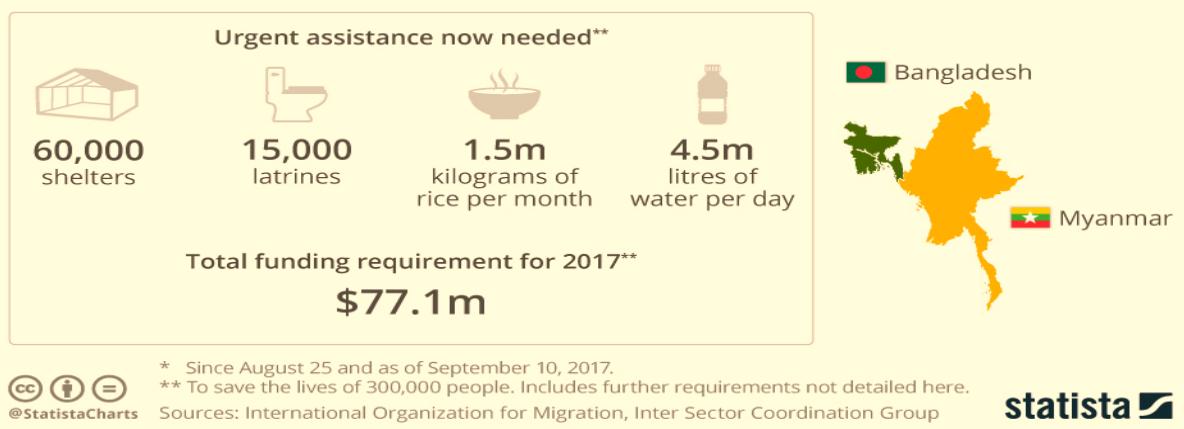

The social context was for the Rohingya ethnic serious, as in 2017 more than 60 thousand have been forced to shelter in Bangladesh, coming from the province of Rakhine, that is one of the more dramatic regions and, for the worst reasons, called by the attention to the Occident media. From the long and difficult 70 years, with the hundred Rohingya death, representing one of the more dramatic and serious humanitarian tragedies that is a reality until nowadays. The severe poverty in straight connection with the religious and cultural traditions, with a humility as a way of being, are characteristics that catch the attention from the Occident to this people unprotected and victim of a unbelievable and unacceptable genocide that needs to be known by the international society and needs an urgent and effective intervention by the international community. In the actuality, this people are facing the discrimination and repression under the Myanmar government that, continue, denying them the citizenship. So, the Rohingya is one of the largest stateless population in the world and almost one million are living in the overcrowded camps in Bangladesh, in order to escape the military's crimes against these human beings. The Rohingya who cannot escape and are still living in Myanmar are confined to camps and villages, without freedom, food, health care, education or livelihoods, being persecute by the government and subject of extreme violence. As we can see from the following data (Figure 9).

\section{Figure 9}




\section{Still fleeing}

Bangladesh, number of Rohingya refugees Cumulative total, '000

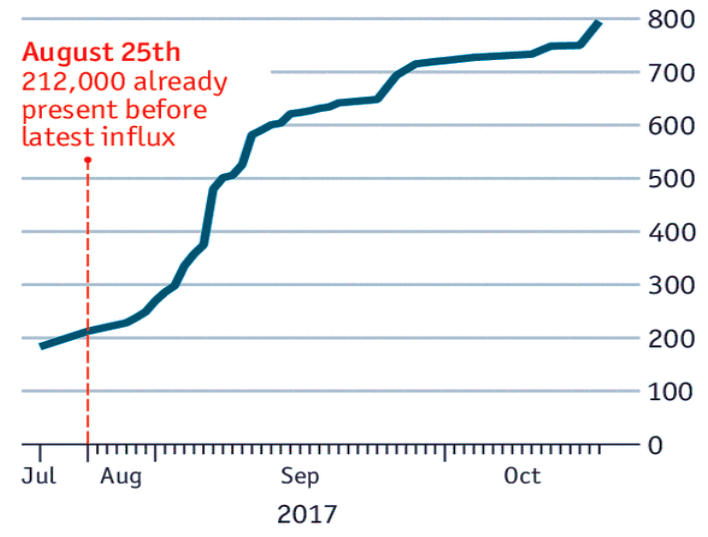

Source: Inter Sector Co-ordination Group

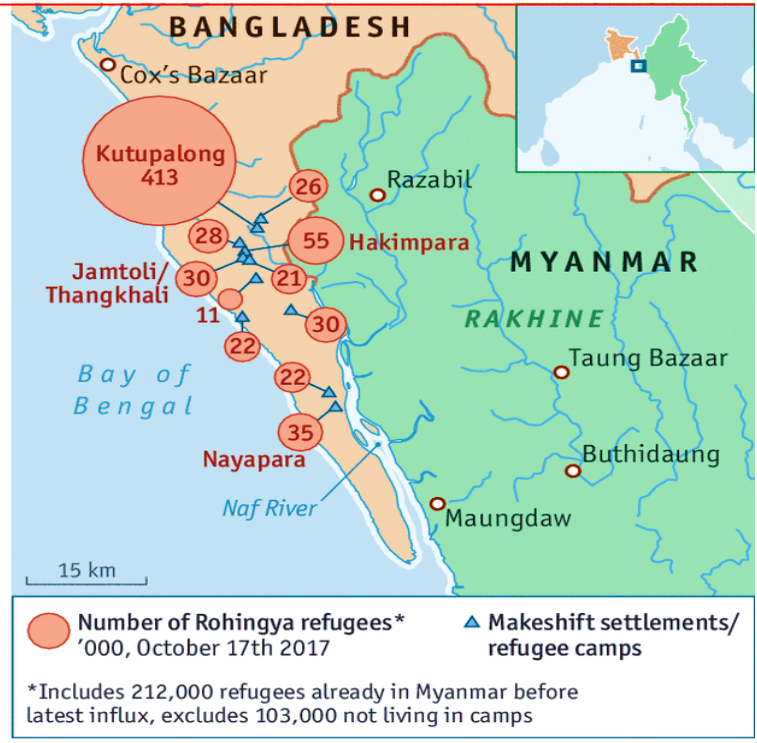

Economist.com

By this graphic demonstration, we can understand the number of Rohingya refugees is growing what represents the increase of the violence and suffering of millions that don't receive the urgent, absolutely need protection and action to effectively stop this genocide and all violence against these human beings. The Human Rights are being violated and the Myanmar state need to be judge but specially, it's an emergency to act in order to avoid more violence and deaths. In fact, in 2019, the International Criminal Court declared the investigation of this crimes against humanity from the military leaders and the violence perpetrated against Rohingya, however there no results worth noting. It's an obligation for the international community, by the international law, the international relations and international organizations.

The Nobel Peace Prize Aung San Suu Kyi, the democracy icon in Myanmar, assumed as a civilian leader amongst the military generals, but in spite of the defending the need of blaming the terrorist and violent activities against Rohingya, is facing the criticism for the powerlessness within the military continuing violence. So, if she was the greatest "promise" of the salvation of this people, the hope of evolution and democracy regimen implementation in his state, known around the world, recognized by the denouncing of violence and the fight for peace and for Human Rights, near different governments in different countries and International Organizations, is now being appointed as inactive concerning defense of the complex Human situation in his own country (Figure 10).

Figure 10

Who are the Rohingya Refugees in Bangladesh?

Key figures related to the Rohingya refugee population in Bangladesh as of 15 November 2018
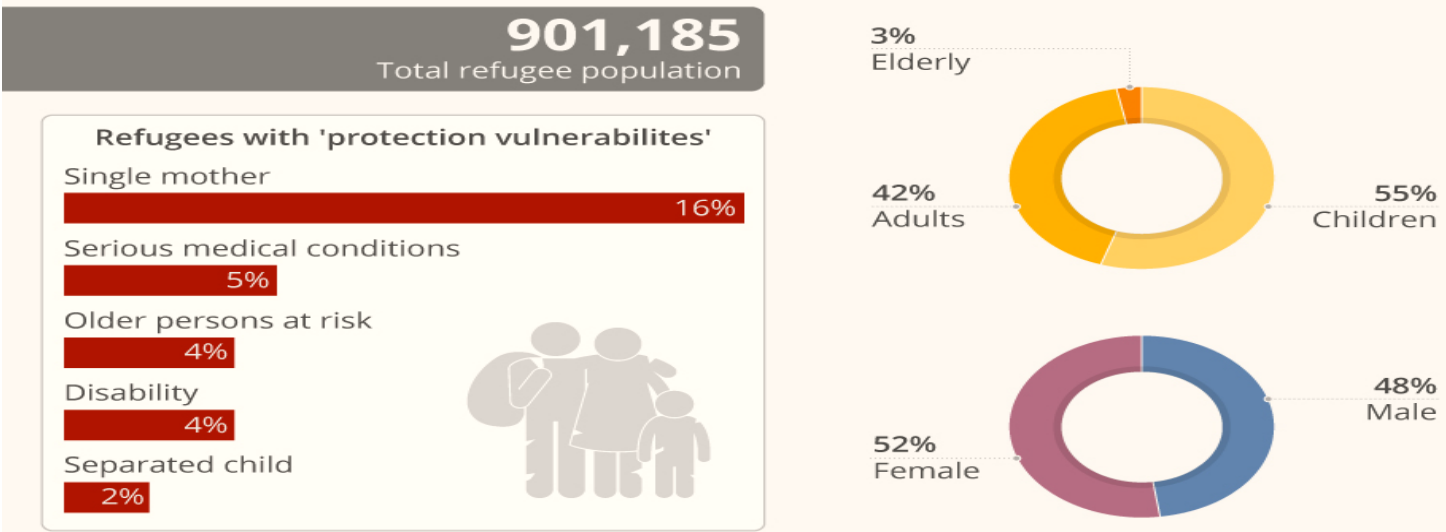

() $\odot \ominus$

@Statistacharts Source: UNHCR 


\section{Modern Slavery and Education as the most important key for the Human Rights protection.}

This is the final part, as result of our research, as we tried to present and prove that Migration and Multiculturalism is not a simple issue, but complex process involving different subjects concerning realities faced by the Humanity around the world, phenomena that have started in the past history, with different "actors", needing the implementation of a effective Education for Human Rights, developing a interdisciplinary diagnostic - political; economical; juridical and judicial; social; religious and cultural identifying the real problems based on real data and asking for the international community attention as requesting the action to prevent violence and protect millions of human beings defenseless (Figure 11).

Figure 11

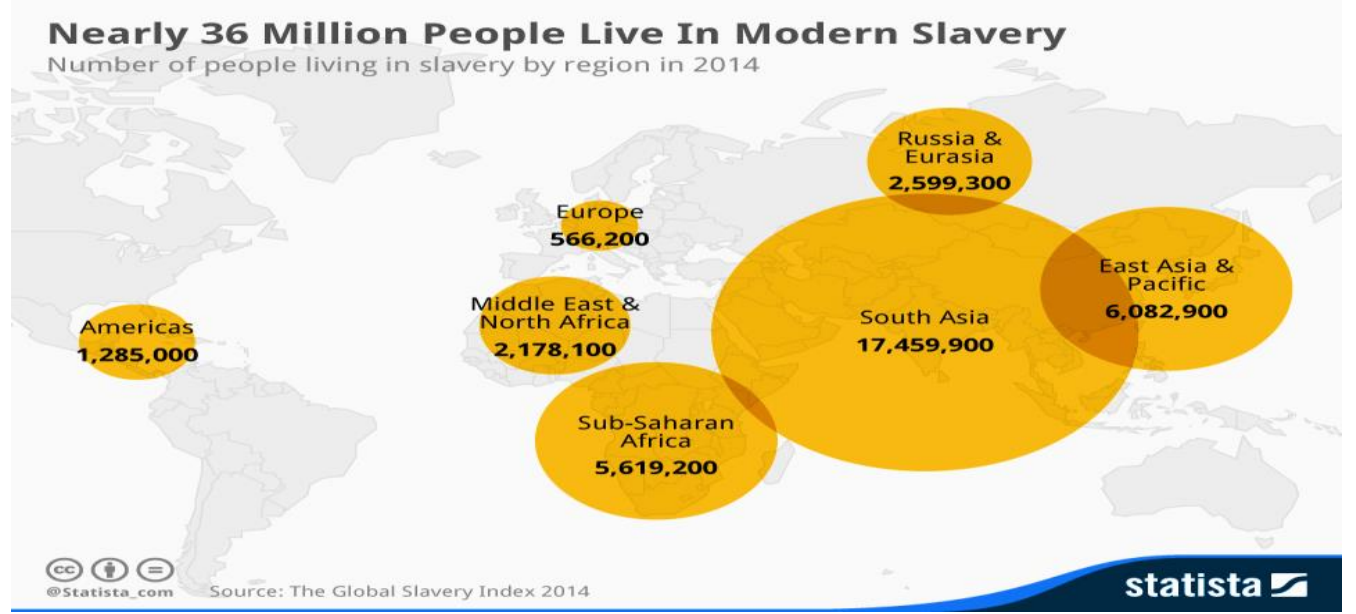

Defining the Slavery as "people forced into labor, debt bondage, trafficking, sexual exploitation for money and forced or servile marriage" (Walk Free's Global Slavery Index), the data collected informs the dramatic numbers, as $0,5 \%$ of the world's population is living as Slaves.

If we analyze the data from the "The Global Slavery Index" we can understand that Slavery remains, although his highest expression is in Asia and Africa than in the Rest of the World. Please compare figures 11 and 12.

Figure 12 


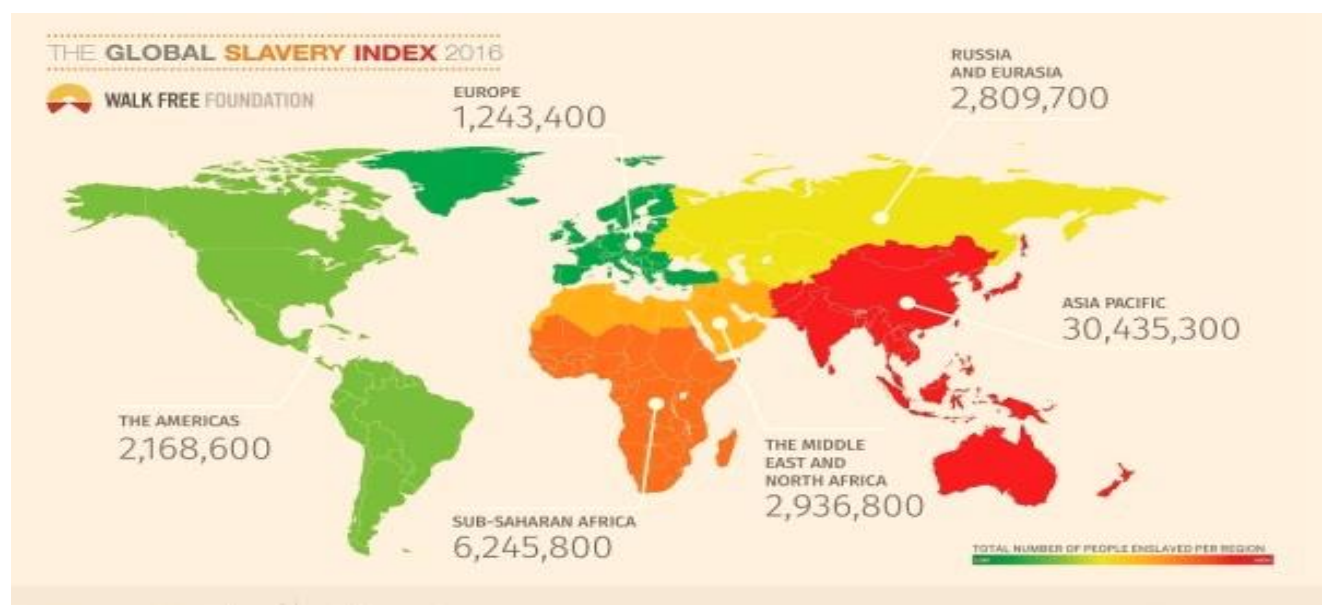

The Human Traffic is the main instrument to catch and move people to the Slavery: in Africa and Middle East mostly children and in Europe and Central Asia the adults, mainly women are the traffic and explored humans. This a dramatic situation as this is not under control but the corruption of (too) many countries and powerful international groups are leading this process that is putting millions under violence and explored, and a large of these people are killed or explored until death. In fact, there are several International Organizations working to prevent or to solve some known situations, but there are inefficient structures overcome for the corrupted and power criminal organizations involving different agents around the world.

And in this analysis, it's easy to identify a crucial element that affects millions but that would be the key to empower people provide the protection (self and social), and particularly promote the evolution of societies and consequently the countries and regions: Education!

As we can analyze in the following graphic, Africa is the continent that have more children in school age, followed by Asia continent. So, the out-of-school children of primary school age, by world region, has been increased, but not enough as the problems and challenges that each country and region is facing, as the lower evolution at all stages of the society; the growing of authoritarian political powers; the exploitation of economic and financial groups; the violence and violation of the fundamental rights of the citizens; the unofficial and radical religious groups manipulating the ideologies in direction to promote control, fear and violence; the submission of millions that live the violation of their rights (Human and Fundamental) by the lack or no information about their legal rights and (possible) protection by the judicial system (national and International), as well as the instruments and legal structures at their disposal. (Figure 13).

Figure 13

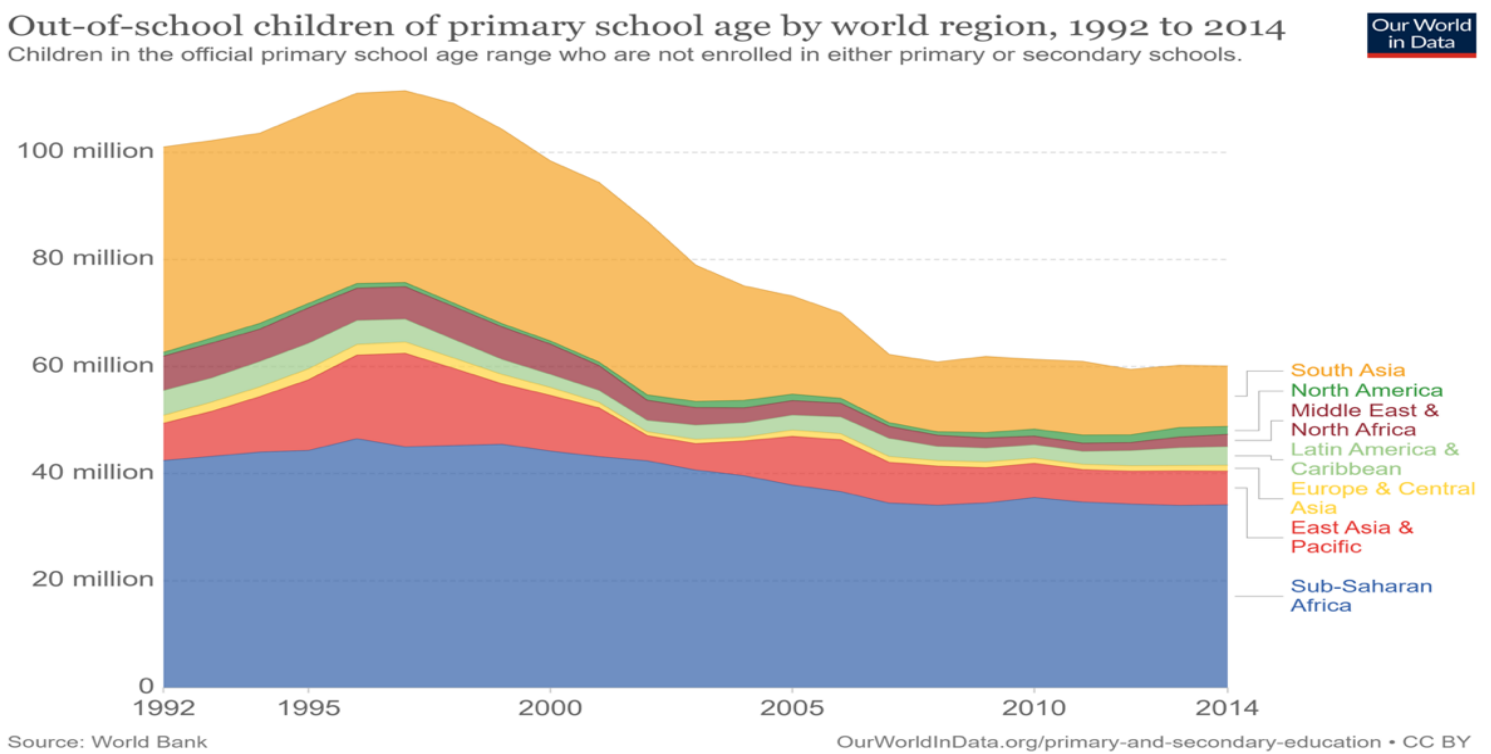


When we compare different world regions, it's possible to conclude that there is still a high number of children who cannot go to school. These are in the regions where the slavery is higher, as Asia and Africa where the population percentage who don't go to school is huge. This evidence is explained in the comparation between figures 11 and 12 with 13.

The Education is a Human Right, a duty to the states and governments, however, in different regions of the world, there are no conditions to have it as a reality to the society.

The result of this context is simple to understand as the following graphic illustrate (Figure 14):

Figure 14

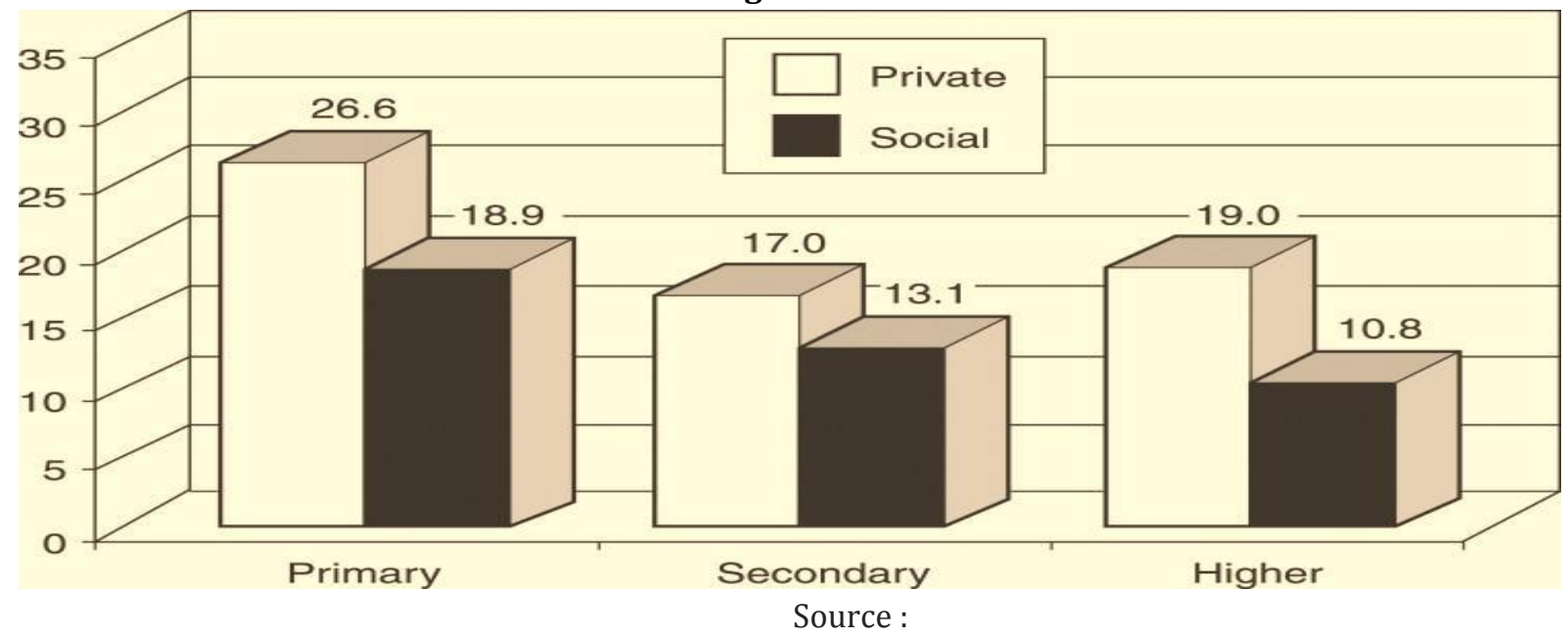

http://documents1.worldbank.org/curated/en/125161468183529864/pdf/REP210000Retur0rnational0comparison.pdf

According to George Psacharopoulos the returns to the states of their investments and, specially, to the citizens that have complete the education is an important analysis: the primary education gives an enormous return in the less developed world, however, by the other side, the higher education is one of the strategic "pillars" of the developed countries. It is easy to understand that the education is always a basic element to the states and defines the possibilities and the dimensions of the evolution of the states, and as much as the countries are developed more and best informed / higher education / skilled people need. There are different possible statements of this study, as the labour market or the development and international affirmation of each country and society. In fact, the education is a right, a Human Right, that needs to be always on top of the missions, protection and promotion of the governments.

\section{Conclusions}

This paper is the result of a long research aiming to prove that Humanity have legal instruments that stablish the end of the slavery, however, we could verify that although those legal instruments abolishing this racial hard racial problem, it continues to be a reality nowadays, including in the developed countries, as in United States of America or South Africa. We achieve to the conclusion that this is a real attack to the human dignity that don't ended.

The world data are a serious demonstration that continents where there a higher number of persons in Slavery are the same where there are the highest number of children that never have the possibility to go to school, meaning that there is a direct relation between the slavery and the scholarship. There is another important conclusion achieved by the world data: the scholarship is a structural element to allow people to achieve better economic conditions and, with this, a better human dignity within the community where it is integrated. So, there are a direct relationship between education and the best living conditions and, by this way, a practical application of the International Treaties.

This research allowed us to conclude that the Humanity in general have enough Juridical Treaties to enable the human being dignity being considered stabilized in all countries worldwide. The reality we can observe from this research is that the different International Organizations, that we have revealed in this paper, demonstrate that the human being is treated inhumanly by other human beings in different countries have just the basis the color difference, religion difference, ethnical difference, gender difference and the educational level difference.

This unequal and inhuman treatment happens both in developed countries, as in the USA, or in developing countries, such as Asian countries, or underdeveloped countries, as in the case of African 
countries. It is clear in this study that the level of education that is denied to a large section of the world population, from which the African continent stands out, means that Humanity as such, and above all represented by the so-called developed countries, has to invest in the education children so that, within spared decades, they can be the structuring factor for the improvement of life in these countries and consequently, removing them in this way from the slavery to which they are currently subjected. There is no doubt that it is through the education of future generations that a direct relationship is reached between the best living conditions, the reduction of inequalities, at all levels and, consequently, the concrete practical and integral application of International Treaties.

\section{References}

BBC News (2020). World of Africa. https://www.bbc.com/news/world-africa46071479?ocid=socialflow_twitter

Choi, J., Dutz, M., Usman, Z. (2020). The Future Work in Africa. International Bank for Reconstruction and Development / The World Bank. ISBN 978-1-4648-1444-0

Hannum, H. (2019). Undermining Old Rights with New Ones: You Can't Always Get What You Want. Cambridge University Press. Pp. 57-79

Mandela Foundation (2020). https://www.nelsonmandela.org/content/page/biography-timeline. Archives and Resources.

Martin, A., Kelly, A., Turquet, L., Ross, S., (2009). Hate crimes: The rise of 'corrective' rape in South Africa. Action Aid.

McCarthy, N. (2017). 6,700 Rohingya Have Been Killed in Myanmar, https://www.statista.com/chart/12279/6700-rohingya-have-been-killed-in-myanmar/

Psacharopoulos, G. (1981) Returns to Education: an updated international comparison. DOI 101080/0305006810170308. https://www.semanticscholar.org/paper/Returns-to-education-\%3Aan-updated-international-Psacharopoulos/e835233cdb6770e57726e3d12030dfd3a8aa5418

Katz, S., Wetzel, J. (2018). Refugee Policies from 1933 until Today: Challenges and Responsibilities, IHRA series, vol. 4, ISBN: 978-3-86331-392-0

Skies, D. (2019). Global Economic Prospects. International. International Bank for Reconstruction and Development / The World Bank. ISBN 978-1-4648-1343-6

Szczepanikova, A., Crieckinge, T. (2018). The Europe of Migration in the European Union. EU Police Lab European Commission. ISBN 978-92-76-01762-2

The Guardian (2020). Slavery Timeline. https://www.theguardian.com/news/2019/aug/15/400-yearssince-slavery-timeline

The Economist (2020). Mandela South Africa. www.economist.com/graphicdetail.

UNESCO (2020). Global Education Steering Committee: how to make the case for safeguarding investment in education. https://en.unesco.org/news/global-education-steering-committee-how-make-case-safeguardinginvestment-education

UNESCO (2020). Revising SDG4 Indicators in anticipation of Post-COVID: Changes in Education Systems. UNESCO Institute for Statistics.

Walker, J., Pearce, C., Boe, K., Lawson, M. (2019). The power of education to fight inequality. Oxfam International. ISBN 978-1-78748-493-1. 